\title{
ECONOMIC VALUATION OF THE Eucalyptus urograndis PRODUCTION IN TWO TYPES OF CONTAINERS
}

\author{
Dariane Priscila Franco de Oliveira ${ }^{1 *}$, Danilo Simões ${ }^{2}$, Magali Ribeiro da Silva ${ }^{3}$

\begin{abstract}
1* São Paulo State University (Unesp), College of Agricultural Sciences, Botucatu, São Paulo, Brazil - e-mail: dariane_franco@ hotmail.com ${ }^{2}$ São Paulo State University (Unesp), Campus of Itapeva, Coordenadoria de Curso de Engenharia de Produção, Itapeva, São Paulo, Brazil e-mail: danilo.simoes@unesp.br

${ }^{3}$ São Paulo State University (Unesp), College of Agricultural Sciences, Department of Forest, Soil and Environmental Sciences, Botucatu, São Paulo, Brazil - e-mail: magali.ribeiro@unesp.br
\end{abstract}

Received for publication: 21/03/2018 - Accepted for publication: 25/01/2021

\begin{abstract}
Resumo
Avaliação econômica da produção de Eucalyptus urograndis em dois tipos de recipientes. $\mathrm{O}$ tratamento sistemático das incertezas associadas aos processos produtivos florestais, permite o estabelecimento de estratégias técnicas-gerenciais para a mitigação do risco inerente à aplicação de capital demando para a produção de mudas. Assim, nosso objetivo foi a análise do risco unitário para a produção de mudas de Eucalyptus usando o método de simulação de Monte Carlo. Pautado na estimativa do cálculo do custo da produção das mudas de Eucalyptus e, nas receitas esperadas de seis sistemas produtivos, caracterizados como projetos de investimento florestal, foi possível a construção dos fluxos de caixa, conseguinte, a adoção de métricas empregadas para a decisão de projetos de investimento mutuamente excludentes. A incorporação da análise de risco teve como proposições as incertezas associadas aos fatores produtivos, aos quais foram atribuídas distribuições de probabilidades. Em seguida, foram gerados números pseudoaleatórios mediante à simulação pelo método de Monte Carlo, com o propósito de mensurar os valores econômicos estocásticos e as probabilidades de ocorrências para as métricas dos projetos. Os resultados estocásticos demonstraram que a probabilidade de viabilidade econômico para as condições analisadas é nula; as variáveis estocásticas mais críticas dos projetos florestais são os investimentos e o ciclo de produção de mudas.
\end{abstract}

Palavras-chave: Risco, custo de produção, Monte Carlo, viveiro, valor presente líquido.

\begin{abstract}
The systematic treatment of uncertainties associated with forest production processes allows the establishment of technical and managerial strategies to mitigate the risk inherent in the application of capital demanded in the production of cuttings. Therefore, the aim of this research was to ascertain the unit risk to produce Eucalyptus cuttings using the Monte Carlo simulation method. Based on the estimate of the production cost of Eucalyptus cuttings and in the expected revenues of six productive systems, characterized as forestry investment projects, it was possible to construct cash flows followed by the metrics used for the decision of mutually exclusive investment projects. The incorporation of risk analysis had as propositions the uncertainties associated with the productive factors, in which probability distributions were attributed. Then, pseudorandom numbers were generated by the Monte Carlo simulation method, with the purpose of measuring the stochastic economic values and the probabilities of occurrences for the project metrics. The stochastic results showed that the probability of economic viability for the analyzed conditions is null. The most critical stochastic variables of forestry projects are investments and the cycle production of cuttings.

Keywords: Risk, production costs, Monte Carlo, nursery, net present value.
\end{abstract}

\section{INTRODUCTION}

The consumption of productive factors, when measured in monetary value applied and mobilized for the forest seedlings production, within an estimated period, that consents in the production cost calculation are considered a premise for the economic evaluation of the forest investment project. However, the monitoring of these factors can be complex, that is, results with potential associated risks can be obtained. In practical terms, when exploring packages that require monetary expenditures and distinct technical and environmental characteristics for the Eucalyptus seedlings production with acceptable growth and quality, associated with the reduction of production costs and, consequently, adding value from forest companies, there are associated uncertainties to the forest investment project.

In this perspective, among the options available in the market, the polyethylene container stands out, which is still widely used. According to Lima et al. (2008), this container is a petroleum-derived polymer, and it implicates a problem since the production sector seedlings forests demand for alternatives to replace the conventional polymer to obtain more compatible materials with the philosophy of environmental preservation. Thus, a container was developed from a cellulosic cylindrical-shape composite, which has a natural process of

FLORESTA, Curitiba, PR, v. 51, n. 2, p. 263-271, abril/jun 2021.

Oliveira, D. P. F. et.al.

ISSN eletrônico 1982-4688

DOI: $10.5380 /$ rf.v51 i2. 58538 
decomposition, to mitigate an environmental problem, intrinsic to the production of forest cuttings. Still, Pias et al. (2015) discuss the importance of the relationship between cutting production and the used container, since it is necessary to find the economic breakeven point, along with high-quality cuttings at acceptable production costs.

This shows the need to perform investment assessments based on the measurement of stochastic economic values and the probability of occurrence of project metrics. That is, in the unit risk analyzes, that is based on the uncertainty about expected cash flows from the project.

For Ferdan et al. (2015) the risk analysis is one of the most important parts of the viability study, once it addresses the identification of major sources of risk, the impact of risk on project stability and financing, and the measures taken to minimize risk. According to Blome and Schoenherr (2011), risk management allows the investor to detect, predict, avoid or reduce the effects of unexpected uncertainties and events, so it is extremely important to identify, analyze, accept, mitigate and monitor risks.

One of the methods used for risk quantification is Monte Carlo simulation, which according Angelotti et al. (2008) the Monte Carlo method has become an expression related to the use of pseudorandom numbers and probability statistics. Gallego and Padilha-Feltrin (2012) complement that Monte Carlo method is used to generate possible scenarios in which its results consider the uncertainty with mean values and standard deviations of the variables of interest, providing the valuable information to the user about the way the investment will behave under uncertainty. The results are then used in a probabilistic risk analysis to identify and avoid possible problems.

In this context, our hypothesis is that the cutting production of a Eucalyptus urophylla $\mathrm{x}$ E. grandis ( $E$. urograndis) hybrid in separate containers and irrigation depths is economically viable, this is, for both polyethylene and degradable containers under different water management. The application of the Monte Carlo method is justified because it is a robust technique for quantitative risk assessment about a problem, especially as a complement to the decision process. Therefore, the aim of this research was to ascertain the unit risk to produce Eucalyptus cuttings using the Monte Carlo simulation method.

\section{MATERIAL AND METHODS}

\section{Experimental data}

The experiment was conducted in the nursery of São Paulo State University (UNESP), Department of Forestry Science, Campus Botucatu. The E. urograndis cutting was produced in the clonal system, therefore, demanded by the rooting, growth and rustification phases. The cuttings were characterized morphologically utilizing height and neck diameter at 90 days for those produced in the polyethylene container according Silva $e t$ al. (2012) and 60 days in a degradable one (VIÉGAS et al., 2018). Six production systems were considered, characterized as investment projects, which included three irrigation depths (10, 12 and 14 millimeters) and two containers (degradable and polyethylene). The most commonly used production cycle for each container was considered, with 90 days for the polyethylene container and 60 days for the degradable one.

\section{Production cost}

The economic evaluation was based on total cost of production (TPC) proposed by Martins (2018). The costing system weighted the items directly related to the productive process of the Eucalyptus cuttings beside the return on capital and expenditure and spending. So, the costs were structured in effective operational cost (EOC), which was composed of variable cost items as expenditures with fertilizers, water, electricity, labor, substrate, and stakes. Added to these, the total operating cost (TOC) was fixed, represented by the depreciation of improvements and equipment, social charges $(44.5 \%)$ and other expenses estimated from $5.0 \%$ of EOC in accordance with Belchior et al. (2017).

\section{Economic valuation}

The monetary values were expressed in United States dollar (USD), so, accordingly, the foreign currency exchange rate measured in units and fractions of the Brazilian real (BRL) was 3.3807 on May 18, 2017.

The economic valuation was based on the real values of the investment projects, i.e., annual gross revenue, annual costs, investment (capital expenditure) required for cash flow construction. Thus, cash flows were considered as conventional and mutually exclusive, weighting a planning horizon of 10-year cash flow. In this analysis, was considered a gross revenue of $20 \%$ over TPC, independently of the applied irrigation depth, since it is a commonly used margin within the forestry market. Was considered the Simplified National Tax (4.0\% of revenues) due the production capacity considered for the nursery, i.e., 300 thousand seedlings per year (UESUGI et al., 2019).

As a premise, the minimum acceptable rate of return (MARR) for investment projects or opportunity cost of capital was determined to indicate to the investor the minimum return required for financial projects approached by Tilahun et al. (2016). Thus, the MARR was projected from the real historical series of the Special System of Settlement and Custody (SELIC) rate observed between January 2008 and January 2016. 
In relation to the quantitative methods of investment analysis, the net present value (NPV), as the main method of evaluation, was used as variables of interest (outputs), as it allows decision-makers to know the cash needs, or the gains of the investment projects, in terms of current monetary units and the profitability index (PI), since it admits to measure the profit generation of the investment projects.

\section{Risk analysis}

From the deterministic models, i.e., from the initial representation of the input and output variables, the stochastic models were constructed. Therefore, the incorporation of risk into financial investment projects occurred from the generation of 100,000 pseudorandom numbers using Monte Carlo simulation method, with the aid of @ Risk 7.1. Mersenne Twister was the algorithm used to generate the pseudorandom numbers because it allows the generation of pseudorandom integer numbers with considerable quality. The correlation between the input variables allowed to obtain Spearman rank-and-order correlation coefficient, $\rho_{s}$, utilizing a nonparametric statistical technique, which varies from -1 to 1 .

The input variables of the stochastic simulation models were Invested Capital (USD k ${ }^{-1}$ ); TPC (USD k ${ }^{-1}$ ); Price (USD k ${ }^{-1}$ ); Production Cycle (days); MARR (\% yr.). A symmetric triangular distribution was considered for all input variables because it did not have a priori information based on Franco et al. (2015). Therefore, a variant of $\pm 15.0 \%$ of the deterministic values was delimited (MIYAJIMA et al., 2018), except for the production cycle that was considered $\pm 10.0 \%$, and for SELIC rate, projected through the decomposition of the time series, by Autoregressive Integrated Moving Average (ARIMA) process (p.d.q.), using the Bayesian Information Criterium (BIC). The construction of the stochastic model considered a correlation matrix, representing the dependence between the risk factors within the same category.

\section{RESULTS}

When analyzing the production cycle, that is, the number of days required for the cuttings to be considered suitable for planting, the value that occurred most frequently in the data set of the cuttings produced in polyethylene containers was 89 days, which allowed the average production of four cycles per year. About to the degradable container, this modal value was 60 days, which resulted in the possibility of six productive cycles per year. From the measurement of direct and indirect costs, that is, the TPC, the value that occurred most frequently for the cuttings produced in $10 \mathrm{~mm}$ irrigation depth (D10) polyethylene container was $85.70 \mathrm{USD} \mathrm{k}^{-1}$ (Table 1), which is the lowest value when compared to other irrigation depths applied.

Table1. Total production cost (USD k ${ }^{-1}$ ) of cuttings produced in a polyethylene container. Tabela1. Custo total de produção (USD mil ${ }^{-1}$ ) em mudas produzidas em recipiente de polietileno.

\begin{tabular}{lrrr}
\hline \multicolumn{1}{c}{ Statistics } & D10 & D12 & D14 \\
\hline Modal value & 85.70 & 86.37 & 87.03 \\
Minimum value & 72.83 & 73.40 & 73.96 \\
Maximum value & 98.47 & 99.23 & 99.99 \\
Standard deviation & 5.24 & 5.28 & 5.33 \\
Probability (\%) & 50.50 & 50.50 & 51.00 \\
\hline
\end{tabular}

D10: $10 \mathrm{~mm}$ irrigation depth; D12: $12 \mathrm{~mm}$ irrigation depth; D14: $14 \mathrm{~mm}$ irrigation depth.

As for TPC of the cuttings produced in a degradable container, the lowest value was obtained for the 10 mm irrigation depth when compared to other depths applied. Therefore, the TPC value that presented the highest frequency was $106.85 \mathrm{USD} \mathrm{k}^{-1}$ (Table 2).

Table 2. Total production cost (USD k ${ }^{-1}$ ) of cuttings produced in a degradable container.

Tabela 2. Custo total de produção $\left(\mathrm{USD} \mathrm{mil}^{-1}\right.$ ) em mudas produzidas em recipiente degradável.

\begin{tabular}{lrrr}
\hline \multicolumn{1}{c}{ Statistics } & \multicolumn{1}{c}{$\mathrm{D} 10$} & $\mathrm{D} 12$ & $\mathrm{D} 14$ \\
\hline Modal value & 106.85 & 107.51 & 108.17 \\
Minimum value & 90.80 & 91.36 & 91.93 \\
Maximum value & 122.76 & 123.53 & 124.29 \\
Standard deviation & 6.54 & 6.58 & 6.62 \\
Probability (\%) & 51.22 & 50.50 & 51.00 \\
\hline
\end{tabular}

D10: $10 \mathrm{~mm}$ irrigation depth; D12: $12 \mathrm{~mm}$ irrigation depth; D14: $14 \mathrm{~mm}$ irrigation depth.

When analyzing the gross income that involved the commercialization of Eucalyptus urograndis cuttings, it can be observed in Table 3 that the highest result obtained with the sale operation was with the cuttings produced with the $14 \mathrm{~mm}$ irrigation depth (D14). 
Table3. Price (USD k ${ }^{-1}$ ) of cuttings produced in a polyethylene container and a degradable container. Tabela 3. Preço (USD mil ${ }^{-1}$ ) de mudas produzidas em recipiente de polietileno e recipiente degradável.

\begin{tabular}{lrrrrrr}
\hline \multirow{2}{*}{ Statistics } & \multicolumn{3}{c}{ Polyethylene } & \multicolumn{3}{c}{ Degradable } \\
\cline { 2 - 7 } & \multicolumn{1}{c}{ D10 } & \multicolumn{1}{c}{ D12 } & \multicolumn{1}{c}{ D14 } & \multicolumn{1}{c}{ D10 } & D12 & D14 \\
\hline Modal value & 102.69 & 103.48 & 104.28 & 128.03 & 128.82 & 129.61 \\
Minimum value & 87.38 & 88.05 & 88.73 & 108.93 & 109.61 & 110.28 \\
Maximum value & 118.15 & 119.06 & 119.97 & 147.29 & 148.21 & 149.12 \\
Standard deviation & 6.29 & 6.34 & 6.39 & 7.85 & 7.89 & 7.94 \\
Probability (\%) & 49.50 & 49.49 & 50.04 & 50.11 & 49.50 & 49.33 \\
\hline D10: 10 .
\end{tabular}

D10: $10 \mathrm{~mm}$ irrigation depth; D12: $12 \mathrm{~mm}$ irrigation depth; D14: $14 \mathrm{~mm}$ irrigation depth.

In this study, the projected MARR was $14.15 \%$, thus considered as the minimum return required by the investor to produce Eucalyptus urograndis cuttings, weighted for investment projects. Concerning the initial investment required to produce Eucalyptus urograndis cuttings, the modal value was $1,919.58 \mathrm{USD}^{-1}$ for polyethylene containers, and 2,206.94 $\mathrm{USD} \mathrm{k}^{-1}$ for degradable ones.

Through the sensitivity analysis, it was possible to identify the correlation of the most critical variables that influence the NPV of financial investment projects (both polyethylene and degradable containers), utilizing Spearman rank-order correlation. This stage allows us to dispose of the variables of interest by order of acuity and to measure the degree of co-relationship. Figure 1 shows that for all irrigation depths applied to polyethylene container cuttings, the initial investment and the production cycle, respectively, have a moderate negative correlation $\left(\rho_{\mathrm{s}}=0.6\right)$.

Polyethylene container (D10)

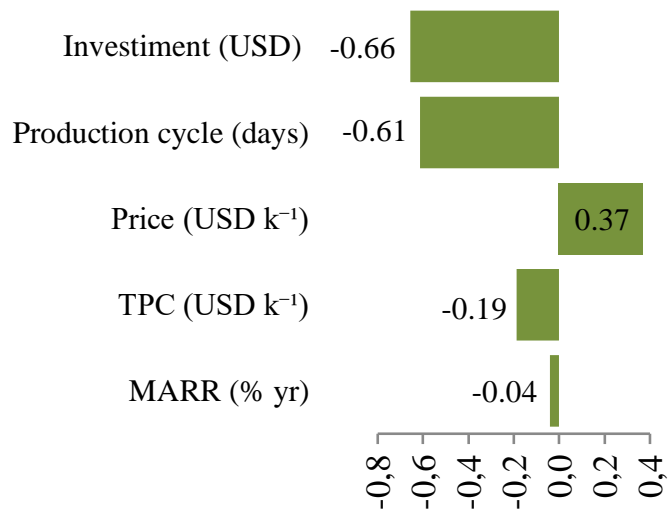

Coefficient value
Polyethylene container (D12)

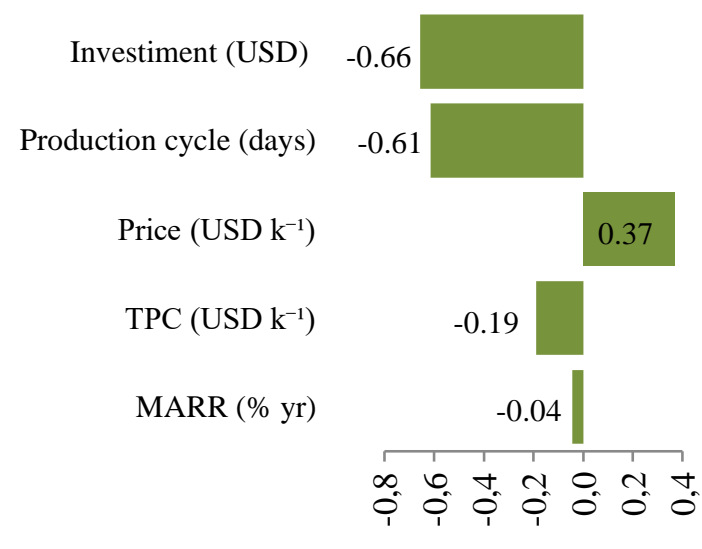

Coefficient value

Polyethylene container (D14)

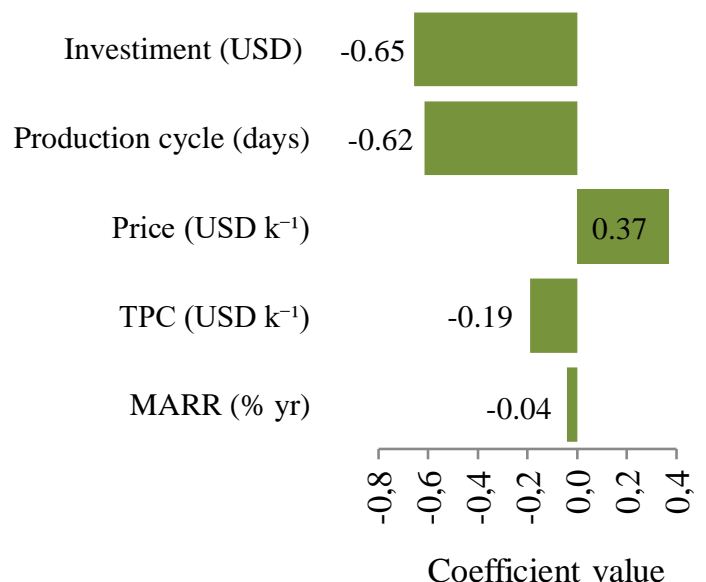

Figure 1. Spearman rank-order correlation coefficient of the input variables of the stochastic simulation model regarding the simulated NPV of the investment projects to produce Eucalyptus urograndis cuttings in a polyethylene container.

FLORESTA, Curitiba, PR, v. 51, n. 2, p. 263-271, abril/jun 2021. 
Figura 1. Coeficiente de correlação posto-ordem de Spearman das variáveis de entrada do modelo de simulação estocástico em relação ao VPL simulado dos projetos de investimento para a produção de mudas de Eucalyptus urograndis em recipiente de polietileno.

For the cuttings produced in a degradable container (Figure 2), the condition of the inputs can be considered similar, since the variables of interest that most negatively impacted the NPV were the production cycle, with moderate correlation $\left(\rho_{s}=0.7\right)$, and the investment with weak correlation $\left(\rho_{s}=0.4\right)$; nevertheless, with rank and degree of importance different from the polyethylene container.

Degradable container (D10)

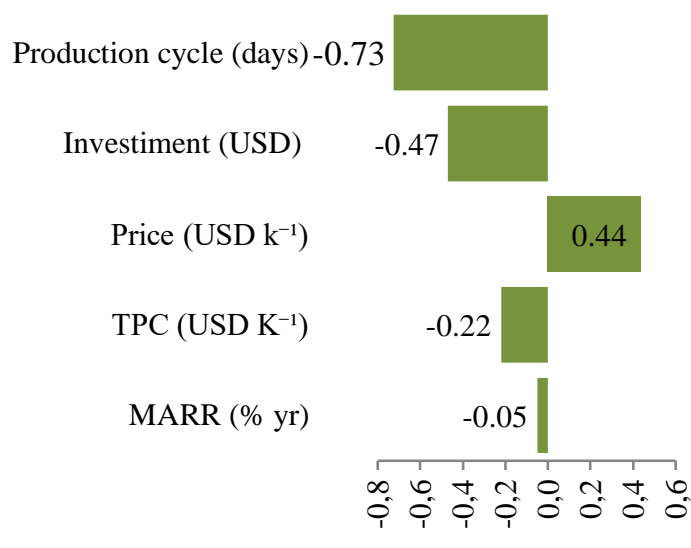

Coefficient value
Degradable container (D12)

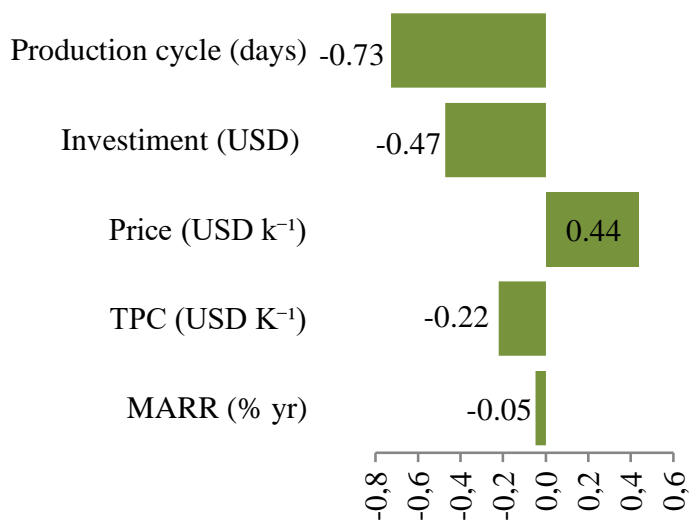

Coefficient value

Degradable container (D14)

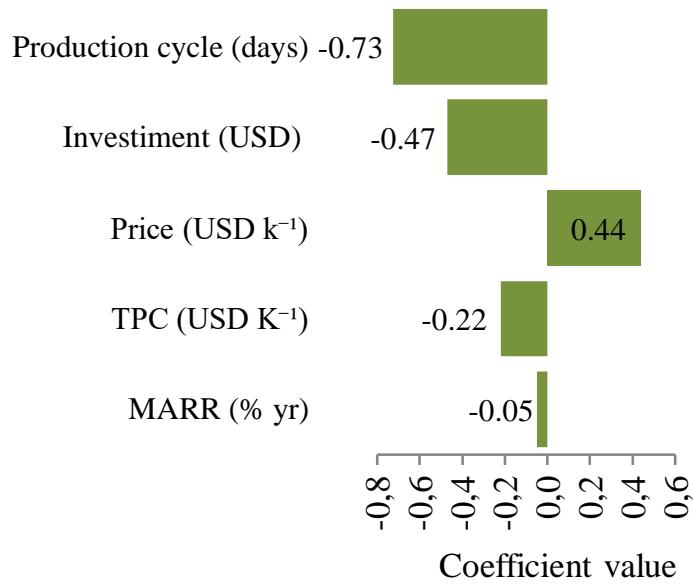

Figure 2. Spearman rank-order correlation coefficient of the input variables of the stochastic simulation model regarding the simulated NPV (USD) of the investment projects to produce Eucalyptus urograndis cuttings in a degradable container.

Figura 2. Coeficiente de correlação posto-ordem de Spearman das variáveis de entrada do modelo de simulação estocástico em relação ao VPL (USD) simulado dos projetos de investimento para a produção de mudas de Eucalyptus urograndis em recipiente degradável.

Due to technical restrictions that prevent the reduction of the initial investment, the number of days required for the cuttings production, and therefore, the total cost of production, the NPV of the investment projects for both containers presented negative modal values (Table 4). The average probability of occurrence is $50.1 \%$, that is, the production of Eucalyptus cuttings for the conditions analyzed is economically unviable and presents a significant financial risk. 
Table 4. Descriptive statistics of the net present value (USD) to produce Eucalyptus urograndis in polyethylene and degradable containers.

Tabela 4. Estatística descritiva do valor presente líquido (USD) para a produção de Eucalyptus urograndis em recipiente de polietileno e recipiente degradável.

\begin{tabular}{lrrrrrr}
\hline \multirow{2}{*}{ Statistics } & \multicolumn{3}{c}{ Polyethylene } & \multicolumn{3}{c}{ Degradable } \\
\cline { 2 - 7 } & \multicolumn{1}{c}{ D10 } & \multicolumn{1}{c}{ D12 } & \multicolumn{1}{c}{ D14 } & \multicolumn{1}{c}{ D10 } & \multicolumn{1}{c}{ D12 } & D14 \\
\hline Modal Value & $-1,476.32$ & $-1,481.96$ & $-1,469.66$ & $-1,393.75$ & $-1,388.78$ & $-1,383.82$ \\
Minimum Value & $-2,143.53$ & $-2,143.35$ & $-2,143.18$ & $-2,447.55$ & $-2,447.28$ & $-2,447.02$ \\
Maximum Value & -741.45 & -734.11 & -726.79 & -146.00 & -133.99 & -122.00 \\
Standard Deviation & 176.60 & 177.36 & 178.12 & 281.64 & 282.98 & 284.33 \\
Probability (\%) & 51.50 & 49.50 & 51.52 & 49.48 & 49.52 & 49.51 \\
\hline
\end{tabular}

D10: $10 \mathrm{~mm}$ irrigation depth; D12: $12 \mathrm{~mm}$ irrigation depth; D14: $14 \mathrm{~mm}$ irrigation depth.

Thus, with the purpose of projecting the NPV greater than zero, i.e., that the investment alternatives are economically viable, an average price of 163.38 USD k$^{-1}$ was adjusted through multiple simulations, for the commercialization of the cuttings produced in a polyethylene container. For cuttings produced in a degradable container, this price should be 164.01 USD k ${ }^{-1}$.

In the PI analysis, for all financial investment projects (both polyethylene and degradable containers), the results obtained (Table 5) confirm that the projects are not financially viable because they do not present an additional return, that is, for each monetary unit invested (USD k ${ }^{-1}$ ) for the production of Eucalyptus urograndis, considering the study conditions, there will be an average loss of 0.30 , that is, $30.0 \%$ of the investment made.

Table 5. Descriptive statistics of the profitability index to produce Eucalyptus urograndis in polyethylene and degradable containers.

Tabela 5. Estatística descritiva do índice de lucratividade para a produção de Eucalyptus urograndis em recipiente de polietileno e recipiente degradável.

\begin{tabular}{lcrrrrr}
\hline \multicolumn{1}{c}{ Statistics } & \multicolumn{7}{c}{ Polyethylene } & \multicolumn{1}{c}{ Degradable } \\
\cline { 2 - 7 } & $\mathrm{D} 10$ & \multicolumn{1}{c}{$\mathrm{D} 12$} & $\mathrm{D} 14$ & $\mathrm{D} 10$ & $\mathrm{D} 12$ & \multicolumn{1}{c}{ D14 } \\
\hline Modal Value & 0.22 & 0.22 & 0.22 & 0.37 & 0.37 & 0.37 \\
Minimum Value & 0.05 & 0.05 & 0.05 & 0.08 & 0.08 & 0.08 \\
Maximum Value & 0.57 & 0.57 & 0.58 & 0.93 & 0.94 & 0.94 \\
Standard Deviation & 0.07 & 0.07 & 0.07 & 0.11 & 0.12 & 0.12 \\
Probability (\%) & 45.52 & 45.52 & 45.52 & 50.50 & 50.50 & 50.50 \\
\hline
\end{tabular}

D10: $10 \mathrm{~mm}$ irrigation depth; D12: $12 \mathrm{~mm}$ irrigation depth; D14: $14 \mathrm{~mm}$ irrigation depth.

\section{DISCUSSION}

By combining the various factors and inputs to obtain a given volume of production of Eucalyptus cuttings, the time of the production cycle is a basic principle to define the optimal total cost of production for each productive level. According to Simões et al. (2012), the reduction of the cuttings production cycle results in a lower economic expenditure

About the production inputs, the lower amount of water required for the cuttings produced in polyethylene container with $10 \mathrm{~mm}$ irrigation depth (D10) resulted in a lower cost of production, that is, resulted variation of $1.5 \%$ in TPC when compared the other irrigation depth. Barbosa et al. (2014) point out that controlling the cost of production is crucial because of the narrow margin of profitability for most crops so that any item can contribute significantly to the final cost. For cuttings produced in degradable container, this production input is also explained as a result of the amount of water used, originating a difference of $1.7 \%$ about to the TPC of the cuttings produced from $14 \mathrm{~mm}$ irrigation depth (D14).

For both containers, water use expenditures were the third most relevant component, which represented about $4.0 \%$ of TPC. Zamberlan and Zamberlan (2011) point out that the use of rainwater is an additional item to be considered in estimating the production costs of irrigated crop activities because it burdens the activity. Thus, undoubtedly, the water used in the production of Eucalyptus cuttings, besides the environmental impact it can cause, has a relevant economic impact on TPC, which corroborates the need to optimize the irrigation depths and systems used.

However, the expenses with permanent labor and with the stakes for both containers, respectively, represented the average of $47.9 \%$ and $12.3 \%$ of the TPC. According to Simões and Silva (2010), labor costs are the ones that most affect the final cost of producing Eucalyptus cuttings. Thus, among the factors expended for production, the labor cost may imply the viability of the investment project. So, labor cost becomes the protagonist

FLORESTA, Curitiba, PR, v. 51, n. 2, p. 263-271, abril/jun 2021.

Oliveira, D. P. F. et.al.

ISSN eletrônico 1982-4688

DOI: $10.5380 /$ rf.v51 i2. 58538 
in the establishment of the cuttings final cost; then a premise to minimize this impact is the optimization of operational productivity. Rodrigues et al. (2007) complement that it is indispensable to optimize the production system using production factors, as the labor, with cost reduction, consequently providing higher income to the investor.

The only flexible variable in the stochastic model is the price of Eucalyptus urograndis cuttings, i.e., the increase in the profit margin, would allow positive results for the NPV, which could indicate whether the financial investment to produce those cuttings is financially viable or not. In general, the selling price is supported by the production cost added with the profit margin, but this price to is associated with the demand of the forestry market, that is, the quantity demanded of cuttings varies in the inverse relation of their price. Therefore, it's worth pointing out, in the economic context of Eucalyptus urograndis seedling production, the margin added to the cost does not necessarily indicate profit.

Dias et al. (2011) analyzed two seedling production systems (seminal and vegetative propagation) of Eucalyptus urograndis, and established the sale price of seedlings and cuttings from 300.00 to $350.00 \mathrm{BRL} \mathrm{k}^{-1}$, also based on the profit margin commonly used within the forestry market and when converted into US dollars is close to that was used in this study. Nevertheless, Machado and Souza (2006) affirm that there is a recognized limitation in imposing a sale price to the market, since many companies consider challenging to establish it, tending to reduce this amount when the market does not accept the calculated price.

The minimum acceptable rate of return (MARR) can be understood as the best rate, which combines low risk and availability to apply the capital under analysis (COELHO; COELHO, 2012). Thus, it is an important concept for the forestry producer's strategic planning, i.e., the use of this rate allows the net present value of the investment project to be considered when considering the future cash flows and the cost for the alternative use of money.

So, one of the conditions to demonstrate the economic-financial viability of an investment project is to present the sum of the present value of all cash flows discounted at the required rate for the project. Thus, Ilha and Campos (2014) affirm that obtaining this value allows quantifying the real economic advantage of the investment, besides being useful in a process to classify mutually exclusive alternatives.

In this context, when analyzing the variables that most influenced the NPV, it was verified that the higher the initial investment and the number of days needed to produce cuttings, the lower the NPV. Among the inputs of the stochastic model, only the price has a positive correlation $\left(\rho_{s}=0,3\right)$, but it is considered weak for the observed sample. It is important to note that the correlation coefficient is independent the units of the variables of measure since it is a dimensionless measure that varies between -1 and +1 .

Despite the affirmation about the correlation is strong or weak appears somewhat dubious character, according to Hinkle et al. (1979) the weak correlation belongs to 0.30 to 0.50 range, and the moderate one when in between 0.50 and 0.70 . So, it can be stated that the investment and the production cycle have a moderate negative linear relation, even if the coefficients are arranged as to the relative dimension for each investment project (containers) on an ordinal scale, the inputs of stochastic models that most impact the NPV.

Thus, for the investment project using a degradable container, the seedling production cycle is the most critical variable, corroborated by the fact of establishing a logical reason that confirms the correlation, i.e., the smaller the number of days required for the production of the cutting, more cycles can be produced, allowing the optimization of the productive process. Even due the difference in the modal value of the initial investment for the production of Eucalyptus urograndis cuttings is approximately $15.0 \%$; the cuttings produced in a degradable container can guarantee greater profitability to the forestry investor. Consequently, it would be the best strategic result for the allocation of the financial resources necessary for the production of Eucalyptus urograndis cuttings.

About PI, Pena et al. (2011) point out that this index is capable of guiding the investor in what the additional return will be from his/her venture, since this measure offers a new interpretation of return, precisely clarifying how many times the initial investment will be multiplied. Therefore, this important indicator of profitability, indicated for all irrigation depth, is not the coverage of the total cost of production.

\section{CONCLUSIONS}

- The stochastic results showed that the probability of the economic success of the analyzed conditions to produce Eucalyptus spp. is zero.

- The cuttings produced from the degradable container with a $14 \mathrm{~mm}$ irrigation depth represent the investment project that provides the least financial loss.

- The increase in the market price of cuttings by approximately $60 \%$ under modal price values makes the investment projects financially viable.

- The smaller average time of the cuttings cycles produced in a degradable container allowed to mitigate the scale problem of financial contributions. 
- For both projects, the investments and the production cycle must be contingent because they present important correlations regarding the net present value.

\section{ACKNOWLEDGMENTS}

The authors would like to thank the Eucatex company for its technical collaboration. The authors are also grateful to the CAPES for financial support.

\section{REFERENCES}

ANGELOTTI, W. F. D.; FONSECA, A. L.; TORRES, G. B.; CUSTODIO, R. Uma abordagem simplificada do método Monte Carlo Quântico: da solução de integrais ao problema da distribuição eletrônica. Química Nova, São Paulo, v. 31, n. 2, p. 433-444, 2008.

BARBOSA, R.M.; HOMEM, B. F. M.; TARSITANO, M. A. A. Custo de produção e lucratividade da cultura do amendoim no município de Jaboticabal, São Paulo. Revista Ceres, Viçosa, v. 61, n. 4, p. 475-481, 2014.

BELCHIOR, I. B.; SABBAG, O. J.; POLINI, D. M. S. S.; PEREIRA, V. G. M. F.; PACHECO, A. Custos e viabilidade econômica na produção de carvão vegetal no estado de Mato Grosso do Sul. Ciência da Madeira, Pelotas, v. 8, n. 3, p. 168-176, 2017.

BLOME, C.; SCHOENHERR, T. Supply chain risk management in financial crises: a multiple case-study approach. International Journal of Production Economics, Amsterdan, v. 134, n 1, p. 43-57, 2011.

COELHO, M. H.; COELHO, M. R. F. Potencialidades econômicas de florestas plantadas de Pinus elliottii em pequenas propriedades rurais. Revista Paranaense de Desenvolvimento, Curitiba, n. 123, p. 257-278, 2012.

DIAS, B. A. S.; MARQUES, G. M.; SILVA, M. L.; COSTA, J. M. F. N. Análise econômica de dois sistemas de produção de mudas de eucalipto. Floresta e Ambiente, Rio de Janeiro, v. 18, n. 2, p. 171-177, 2011.

FERDAN, T.; SOMPLÁK, F.; ZAVIRALOVÁ, L.; PAVLAS, M.; FRÝBA, L. A waste-to-energy project: a complex approach towards the assessment of investment risks. Applied Thermal Engineering, Oxford, v. 89, p. 1127-1136, 2015.

FRANCO, M.; VIVO, J. M.; HERRERÍAS, R. A quick assessment from expert judgements to assist in farmland valuation. Land Use Policy, Guildford, v. 46, p. 324-329, 2015.

GALlEGO, L. A.; PADILHA-FELTRIN, A. Power flow for primary distribution networks considering uncertainty in demand and user connection. International Journal of Electrical Power \& Energy Systems, Oxford, v. 43, n. 1, p. 1171-1178, 2012.

HINKLE, D. E.; WIERSMA, W.; JURS, S. G. Applied statistics for the behavioral sciences. Chicago: Rand McNally College Publishing, 1979, 489 p.

ILHA, M. S. O.; CAMPOS, M. A. S. Quality of investments in rainwater harvesting systems: Particles Swarm Optimization for maximization of net present value. Engenharia Sanitária e Ambiental, Rio de Janeiro, v. 19, n. 4, p. 373-382, 2014.

LIMA, S. M.; LIMA, M. A. G. A.; ALMEIDA, Y. M. B.; VINHAS, G. M. Polyethylene/amphiprotic blends as alternative for decreasing plastics residues in the environment. Polymer Bulletin, Berlin, v. 60, n. 2, p. 301-311, 2008 .

MACHADO, D. G.; SOUZA, M. A. Análise das relações entre a gestão de custos e a gestão do preço de venda: um estudo das práticas adotadas por empresas industriais conserveiras estabelecidas no RS. Revista Universo Contábil, Blumenau, v. 2, n. 1, p. 42-60, 2006.

MARTINS, E. Contabilidade de custos. São Paulo: Atlas, 11 ed. 2018. 408 p.

MIYAJIMA, R. H.; BARRETO, V. C.; OLIVEIRA, P. A.; BATISTELA, G. C.; SIMÕES, D. Risk Analysis of the economic benefits of Ochroma pyramidale: a case study of forest planting in Brazil. Journal of Agricultural Science and Technology, New York, v. 8, p. 444-453, 2018.

PENA, H. W. A.; HOMMA, A. K. O.; SILVA, F. L. Análise de viabilidade econômica: um estudo aplicado a estrutura de custo da cultura do dendê no estado do Pará- Amazônia-Brasil, 2010. Revista Oídles, Málaga, v. 5, n. 11, p. 1-24, 2011.

FLORESTA, Curitiba, PR, v. 51, n. 2, p. 263-271, abril/jun 2021. 
PIAS, O. H. C.; BERGHETTI, J.; SOMAVILLA, L.; CATARELLI, E. B. Qualidade de mudas de cedro em função da utilização de fertilizantes e recipientes de diferentes tamanhos. Revista Agroambiente On-line, Boa Vista, v. 9, n. 2, p. 208-213, 2015.

RODRIGUES, E. R.; CULlEN JR, L.; BELTRAME, T. P.; MOSCOGLIATO, A. V.; SilVA, I. C. Avaliação econômica de sistemas agroflorestais implantados para recuperação de reserva legal no Pontal do Paranapanema, São Paulo. Revista Árvore, Viçosa, v. 31, n. 5, p. 941-948, 2007.

SILVA, R. B. G.; SIMÕES, D.; SILVA, M. R. Qualidade de mudas clonais de Eucalyptus urophylla x E. grandis em função do substrato. Revista Brasileira de Engenharia Agrícola e Ambiental, Campina Grande, v. 16, n. 3, p. 297-302, 2012.

SIMÕES, D.; SILVA, M. R. Análise técnica e econômica das etapas de produção de mudas de eucalipto. Revista Cerne, Lavras, v. 16, n. 3, p. 359-366, 2010.

SIMÕES, D.; SILVA, R. B. G.; SILVA, M. R. Composição do substrato sobre o desenvolvimento, qualidade e custo de produção de mudas de Eucalyptus grandis Hill ex Maiden x Eucalyptus urophylla S. T. Blake. Ciência Florestal, Santa Maria, v. 22, n. 1, p. 91-100, 2012.

TILAHUN, M.; DAMNYAG, L.; ANGLAAEREC, L. C. N. The Ankasa Forest Conservation Area of Ghana: Ecosystem service values and on-site REDD + opportunity cost. Forest Policy and Economics, Amsterdam, v.73, p. 168 - 176, 2016.

UESUGI, G.; SIMÕES, D.; MORAES, C. B.; SILVA, M. R. Economic and Financial Analysis of Tree Seedling Production Using Composted Biosolids Substrate. Floresta e Ambiente, Seropédica, v. 26, n. 2, p. 1-9, 2019.

VIEGAS, L. B. SIMÕES, D.; LIMA, K. B.; SILVA, M. R. Water Management for Schinus terebinthifolius Raddi seedlings in degradable containers. Floresta e Ambiente, Seropédica, v. 25, n. 1, p. 1-7, 2018.

ZAMBERLAN, J. F.; ZAMBERLAN, C.O. Irrigação: Gerenciamento de Custos como Ferramenta na Tomada de Decisão. Revista em Agronegócio e Meio Ambiente, Maringá, v. 4, n. 3, p. 391-408, 2011. 